\title{
Intertextualité,allégorie et allusions bibliques dans Moses, Man of the Mountain de Zora Neale Hurston
}

\author{
Dr. Alassane Abdoulaye DIA* \\ Ph.D. in African \&American literatures, Université Gaston Bergerde Saint-Louis, Sénégal
}

*Corresponding Author:Dr. Alassane Abdoulaye DIA, Ph.D. in African \&American literatures, Université Gaston Bergerde Saint-Louis, Sénégal

\begin{abstract}
This paper is a contribution to the studies on Zora Neale Hurston's Moses, Man of the Mountain, a historical novel that has catches critical attention for more than one reason. The novel is described as a political satire and raises questions about the material upon which its fabric is based. The study is particularly interested in the novel's style and narrative strategies in order to decipher Hurston's text and help better understandthe novel which contains a great many biblical allusions and allegories with particular aesthetics that the author brings out through intertextuality.

The famous African-American figure draws her story from Judeo-Christian mythology and reproduces the story of the "Book of Exodus" from The Old Testament, then rewrites or even reinvents it for aesthetic and social purposes. Such a strategy places her novel also called "biblical narrative" at the intersection of history and fiction. Using a socio-critical and stylistic approach, the paper exploits Hurston's narrative strategies and expounds the many biblical allusions and references that mark the novel. The analysis concludes that Hurston's historical novel has a universal dimension, but can, at several levels, be exploited from a racial perspective, which links it directly to the political and economic history of the USA in the midst of change and in times of racial discrimination.
\end{abstract}

Key words:Historical novel, intertextuality, allegory, biblical reference, aesthetic, Judeo-Christian mythology

\section{INTRODUCTION}

Publiéen 1939, et troisième roman de Zora Neale Hurston, Moses, Man of the mountainse qualifie de roman historique dans lequel l'auteur réécrit, voire réinvente l'histoire des Hébreux et des Egyptiens du Livre de l'Exode deL'Ancien Testament.Dans ce roman souvent dénommé "récit biblique", l'auteurdonne une autre version de l'histoire.

Moses, Man of the Mountain est publié au début de la Deuxième Guerre mondiale et se définit comme un roman politique succédant à TheirEyesWereWatchingGod (1937) qui est le chef-d'œuvre de l'auteur. Il a une posture de satire politiqueassortie d'une esthétique particulière. Le roman est paru dans une période où le monde entier a connu un bouleversement politique et socio-économique; lequel mal a secouéplusieurs sociétés et les a plongéesdans d'énormes difficultés d'ordre politique, social, racial, etc.

Un tel contexte a probablement inspiré Hurston à donner à son roman une dimension plus universelle que toutes ses autresœuvres de fiction. Car "cette génie anthropologue de formation, folkloriste et ancienne étudiante et disciple du Dr Franz Boas" (Cf. Dia, 2020)[1], a exploité l'histoire du "Livre de l'Exode" de façon astucieuse et l'a modifié pour des fins esthétiques et littéraires.Son roman se lit dans une perspective universelle, mais peut être étudié par analogies dans un contexte particulier des USA en pleine mutation eten période de ségrégation raciale.

En lisant Moses, Man of the Mountain, un lecteur moins averti aurait l'impression que l'auteur, étant américaine de par sa nationalité et noire de par son appartenance raciale, n'aborde pas directement les problèmes de sa propre société, car on n'y trouve pas de personnage noir ni américain. Nonobstant cette remarque, des pistes de lecture nemanquentpas pour décoder ce roman historique.Ainsi, l'une des meilleures approches de l'œuvre est de l'étudier dans une perspective sociocritique en exploitant 
profondément les stratégiesnarratives déployées par l'auteur à savoir l'intertextualité et la narration cosmogonique.

Une telle exploitation des stratégies narratives utilisées aide les lecteurs moins outillés à mieux saisir le texte de Hurston; surtout en ce qui concerne les références et allusions bibliques. Pour ce cas précis, la principale source d'inspiration de l'auteur est la mythologie judéo-chrétienne à partir de laquelle Hurston remonte à l'histoire et produit un texte qui se place à l'intersection de l'histoire et de la fiction. C'est dans ce sens que nous nous invitons à contribuer aux recherches menées sur cette grande figure de la Renaissance de Harlem etactiviste des droits civils des Noirs américains.

Notre étude repose essentiellement sur une approche à la fois sociocritique et stylistique et cherche à étayer les éléments cachés ou codés qui fondent la fabrique de Moses, Man of the Mountain (dans notre analyse nous utiliserons l'abréviation $M M M$ pour les passages titrés du roman).Pour ce faire, nous traiterons d'abord l'intertextualité basée sur la mythologie judéo-chrétienne, puis développerons l'allégorie et les allusions bibliques liées au personnage éponyme et à quelques symboles du texte.

\section{DE L'INFLUENCE DE LA MYTHOLOGIE JUDEO-CHRETIENNE}

Dans l'histoire générale, l'on constate que la mythologie occupe une place centrale dans la vie des humains. C'est même une référence à plusieurs niveaux. L'une des plus célèbres, voire anciennes est la mythologie grecque qui puise dans celle sumérienne.Cependant, la première reste une source orale à partir de laquelle beaucoup de faits historiques ont été appréhendés et reconnus comme sources fiables. Fort de ce constat, les sociétés traditionnelles négro-africaines et américaines puisent dans ce trésor culturel qu'elles partagent avec tant d'autres traditions populaires. Une telle pratique laisse voir ses empreintes dans la littérature américaine, particulièrement la branche africaine-américaine qui se veut une littérature d'émancipation.C'est l'idée que défendent P. Suresh et D. Angeline Jeba(2018) quand ils affirment:

Zora Neale Hurston's Moses, Man of the Mountain (1939), is a unique and familiar work where Zora beautifully blends fiction, religion and humour creating one of the most intriguing works in African American literature. This novel based on the familiar story of the Exodus, Zora Neale Hurston blends the Moses of the Old Testament with the Moses of black folklore and song to create a compelling allegory of power, redemption and faith and narrated in a mixture of biblical rhetoric, black dialect and conversational English (118).[2]

Hurston, connue par son talent de folkloriste et d'anthropologue, est une figure remarquable dans la littérature africaine-américaine. Dans Moses, Man of the Mountain, ellemet en exergue les aspects dont nous avons fait mention plus haut avec une esthétique particulière. Dans cette partie, nous allons montrer commentcette talentueuse écrivain femme, fait usage du folklore à travers l'intertextualité pour présenter un œuvre profondément ancrée dans la tradition du roman historique. Comme le savent les lecteurs avérés, ce type de roman est dit essentiellement politique.

Uneautre particularité du roman deHurston, au-delà de son caractère politique, comme le veut la tradition, est son ancrage dans la mythologie judéo-chrétienne qui fait du texte un matériauteinté d'images et de symboles bibliques à travers une intertextualité frappante. Bien que fréquent chez les critiques comme chez les lecteurs, il n'est pas toujours trivial de définir ce terme clé de notre analyse. Selon les Etudes littéraires en ligne: «L'intertextualité est l'ensemble des relations qu'un texte entretient avec un ou plusieurs autres textes » (citations, allusions, références)[3].De ce fait, l'on remarque que Hurston a non seulement puisé dans la mythologie judéo-chrétienne mais également reproduit l'histoire du peuple hébreu et des Egyptiens dans L'Ancien Testamentpour des fins littéraires et sociales.En étudiant l'intertextualité, il estaussi important de rappeler la théorie de Julia Kristeva qui a forgé le moten 1966 et l'a définie comme «tout texte se construit comme une mosaïque de citations, tout texte est absorption et transformation d'un autre texte.» [4]

Ces aspects sont alors très apparents dans Moses, Man of the Mountainet se perçoiventà travers le mythe et la légende qui donnent au roman deHurstonun cachet culturel ou plus précisément «un timbre » [5] pour reprendre Alioune Tine (1985). L'objectif principal de cette représentation est de faire ressortir une affirmation d'une identité culturelle. Cette astucieuse stratégie littéraire est bâtie sur de référencesbibliques qui renvoient beaucoup à la mythologie judéo-chrétienne. Ainsi, l'auteur l'assure esthétiquementà travers une narration cosmogoniquecaractérisée par un magicalrealism. 
A propos du magicalrealism, il serait judicieux de procéder à une définition succincte des termes «mythe » et «légende» pour une meilleure compréhension de notre travail. Selon Dictionnaire des mythes littéraires, mythe signifie un: «récit populaire ou littéraire mettant en scène des êtres surhumains et des actions imaginaires, dans lesquels sont transposés des évènements historiques, réels ou souhaités, ou dans lesquels se projettent certains complexes individuels ou certaines structures sous-jacentes des rapports familiaux et sociaux.» [6]Quant à la légende, il la conçoit comme un «récit à caractère merveilleux, où les faits historiques sont transformés par l'imagination populaire ou par invention poétique.»[7]

Sil'on essaie d'appréhender le mythe et la légende tels quels, l'on s'aperçoit nettement que chaque société a sa propre mythologie et cosmogonie. Le mythe comme la légende existent côte à côte dans toutes les sociétés et varient selonla culture et l'époque. Aussi, convient-il de soulignerdans l'œuvre de Hurston, qu'avant de devenir une célèbre légende, Mosesle personnage éponyme s'est intéressé à faire des investigations sur la notion de «cosmogénèse » qui est le fondement de l'existence des mortels. A cette fin, il se confie au patriarcheMentu qui lui apprend la sagesse de base. Moses lui pose une panoplie de questions métaphysiques dont la plus importante s'intéresse à l'origine du monde, c'est-à-dire comment Dieu a créé le ciel et la terre. Une telle scène ou fait suscite beaucoup de curiosité et renvoie au domaine du religieux particulièrement à la Genèse.

En réalité, dans le projet d'écriture de Hurston, il s'agit bien de la fiction, mais la légende de Moses est inspirée par celle de Moïse personnage de la Bible. C'est pourquoi son héros apparait dans le roman d'abord comme un personnage ordinaire pour ainsi incarner une grande personnalité que Dieu lui a procurée. Ce potentiel prophète chezHurston, va alors faire face à l'annonce de sa révélation après tant de questionnements auprès du sageMentu, son mentor. Ses échanges avec Mentu ont fait l'objet de conversations intéressantes sur le phénomène mythique de la création du cosmos que le narrateurpartage en ces termes: 'Moseslearned how God made the first day. He had ordered the covering robe stripped from the sun. Why had He done so? Well, you see, He had made the firmaments. He had hammered out the great bowl of investing firmament and starred it with rivets' (MMM, 38).

Même une lectureélémentaire de ce passage renseignera que le mythe n'est pas facile à comprendre. Il relève souvent d'un pouvoir mystique ou d'aspects surnaturels que l'on ne peut pas comprendre rationnellement comme un simple fait. Tout de même, cela reste un pouvoir de Dieu et un mystère de la vie dont un simple mortel ignorera totalement la cause. Car, Dieu, son créateur, a fait de lui un être imparfait, voire curieux et insatisfait. Par conséquent, il arrivera toujours des choses que les mortels ne seront à même de comprendre sans un certain pouvoir ou don. Tel était le cas de Moses qui ne savait pas qu'il avaitun don, alors que le sage patriarcheMentule savait bien. C'est pourquoi ce dernier s'intéresse à lui et Moses, à son tour, se rapproche du mentor pour comprendre la situation en s'initiant à la sagesse. Cette scène en ditassez:

An elderly Egyptian statesman sitting directly behind Pharaoh leaned forward and whispered 'Did you see what I saw? I believe we have a great military leader on our hands."

"Don't I know it? I intend to keep working on that boy until I make a great soldier out of him. [...] We have a military genius in Moses. I shall instruct him further." $(M M M, 50)$

Moses ne savait pas qu'en lui dort un prophète qui serait un messie et une célèbre légende à travers le monde. Pourtant, il cherche loin à comprendre le fondement du monde dans lequel il évolue. Peut-être même, la série de questions qu'il posait à Mentu est une manifestation du processus qu'il aura à suivre. Dans ce questionnement, il s'est intéressé au miracle de la vie à savoir la division du monde en deux parties: la nuit et le jour. Ceci peut aussi s'expliquer par le fait que le monde est naturellement complexe; il se caractérise par une opposition binaire qui se manifeste à travers ses hauts et bas en sus de sa bipolarisation. Moses ne cesse des'interrogersurcesfaitsmiraculeux:

"Then why do we have nights between days?" Moses asked. "Well, He is still working on the world and He must hide His hand from us humans. That is why things grow at night. Most things are born in the mothering darkness and most things die. Darkness is the womb of creation, my boy. But the sun with his seven horns of flame is the father of life." (MMM, 38-9)

Il convient de retenir que pour croire au mythe et à la légende, il faut d'abord savoir que l'on ne peut pas tout comprendre. Néanmoins, si l'on croit au mythe à un certain degré, l'on comprendra beaucoup de choses avec une réalité que la légende révèleau fil du temps. C'est pourquoi, nous affirmons que c'est un processus à travers lequel Moses a pris conscience de son génie. Il s'en est suivi un miracle 
qui s'installé en lui. Pour preuve, Moses commence à montrer les effets des enseignements du sage patriarche Mentu.

Par conséquent, Moses incarne la sagesse et adopte un autre langage plutôt codé. D'ailleurs, il le justifie par le miracle de Dieu et appréhende le mythe du soleil par ce langage codé et imagé qui dépasse ses pairs. Ceci montre qu'il a maintenant pris conscience de son initiation et cela se manifeste dans ses paroles d'abord devenuesnon seulement sacrées mais aussi mystérieuses, car il est aussi doté d'un pouvoir magique :

"Before the old man becomes a child again." When Moses said that, he was telling his thoughts by pictures. The people said that Horus, the sun-god of the two horizons, became a baby each morning at sunrise and grew older all day long. By sundown he was an old man with a beard. But during the night his mouth returned and he rose the next morning in his red glory and with watchful eye and drove away all darkness. (MMM, 73).

Au fait, cette référence à la mythologie judéo-chrétienne est pleine de sens. Hurston fait, ici, usage du mythe, par intertextualité, pour déconstruire le discours de Pharaoh. On y voit une représentation de rapport de forces entre ce dictateur et l'armée de Mosesà travers une opposition de deux mythes:Pharaoh, l'oppresseur du peuple d'Israël qui est dans le roman l'emblème du 'Pillar of Fire' et Moses qui est l'incarnation du 'Pillar of Water' qui va éteindre la flamme de Pharaoh dont la fin symbolise la chute de son pouvoir. Moseslui-même annonce et confirme un tel défi à son peuple : 'Don'tgetsoexcited about nothing! The Lord is going to fight for you as he's been doing all along. Stand still and see the salvation of the Lord, which he is going to show you today $(M M M, 190)$.

Moses prépare son peuple à la victoire et en appelle au sens du dévouement et de la détermination pour combattre l'injustice et renverser le pouvoir. Le narrateur le témoignedansce passage:

Moses just stood and looked and the pillar of cloud that went before the host moved around from the sea and spread itself like a great plumery curtain between the Israelites and Pharaoh and hid each camp from the other. The Israelites felt shut in safe. The Egyptians felt shut out and puzzled. [...] But Moses never slept. The signal pillar of fire glowed behind the cloud screen and lighted the camp of Israel. Moses himself went back to the sea wind and stood. When the hour came he called up the east wind and stretched out his hand. They broke the head of the eastern drum and marched out on the sea. The retreating tidal waters did not creep on as their habit, they fell back from the strait on either side like two mighty armies in retreat.[...] The waters fled back and back and back and stood in a solid wall on either and waited on the powers to close them up again.

Then Moses ordered the march [...] the bones of Joseph crossed after the women and children. Then Moses challenged Pharoah. The smoky cloud screen lifted. The fiery pillar again went before the hosts and the sentries of the Egyptian army saw that the children of Israel were escaping across the sea and ran to wake up the camp. (MMM, 190-191).

À travers ces faits, on a une idée des sociétés traditionnelles et leur culte quand il s'agit de conjurer un malheur ou de voir comment s'y prendre avec recours au mythe. De tels faits ne sont pas seulement évoqués pour proférer des paroles mystiques mais plutôt pour éveiller le peuple hébreu et le guider à surmonter les problèmes qui sévissent dans la société. C'estde là que ressort l'esthétique du romande Hurston queHenry Louis Gates Jr. magnifie dans ces lignes:

In this 1939 novel based on the familiar story of the Exodus, Zora Neale Hurston blends the Moses of TheOld Testament with the Moses of the black folklore and song to create a compelling allegory of power, redemption, and faith. Narrated in a mixture of biblical rhetoric, black dialect, and colloquial English Hurston traces Moses' life from the day he is launched into the Nile river in a reed basket, to his development as a great magician, to his transformation into the heroic rebel leader, the Great Emancipator. From his dramatic confrontations with Pharaoh to his fragile negotiations with the wary Hebrews, this very human story is told with great humor, passion, and psychological insight - the hallmark of Hurston as a writer and champion of black culture.[8]

Moses le personnage éponyme joue le rôle de libérateur et fonde ses discours sur une rhétorique biblique. Il use des contes à travers lesquels il instruit son public. Dans ces contes, les acteurs en question sont des animaux, mais il fait allusion à des êtres humains.

Le peuple hébreu subit énormément d'injustices de la part de Pharaoh leur oppresseur qui se prend pour un détenteur éternel du pouvoir. Ce dernier ne se souciant pas de l'intérêt commun du peuple 
qu'il dirige ne cherche ainsiqu'à consolider son pouvoir et à utiliser la répression comme arme de défense et moyen de communication. Cependant, les leçons de morale enseignées dans les contes ayant comme fait réel un rapport de forces sont évocateurs de cette loi de la jungle. C'est ce qui pousse la critique à faire autant d'analogies et à comparer ce monde paradoxal à celui des animaux. OrquideaRibeiro (2011) l'analyse avec perspicacité:

The domain of talking about animals is closely related to African mythology and AfricanAmerican culture. The animal tales did not provide sheer amusement to Moses; later on in his life, Moses will use cosmic folktales to teach the Hebrews valuable lessons. Before the battle with the Amalekites, Moses explains the importance of the upcoming conflict using a folktale about the rabbits and frogs, a tale that also appears in Mules and Men, her collection of southern Negro folklore (p.06). [9]

L'on constate que la représentation du monde des humains par celui des animaux a une forte influence sur la création romanesque de Hurston. Cela est même apparentdans la psychologie des personnages qui vivent dans un désespoir total. Cependant, la force supérieure représentée par Pharaohne va pas rester sans remèdes; des initiatives sont prises pour paralyser le système. Ces initiatives se manifestent à travers les sensibilisations du héros.

Les contes que Mosesraconte ne sont pas que divertissants à son peuple; ils sont également porteurs de message d'éveil de conscience. Moses lui-même montre qu'il n'est pas du tout conteur au sens d'un rêveur mais plutôt un sensibilisateur et un éclaireur:

'Those frogs are sacred because of us. We don't need to kill ourselves no more because something in the world is happy again. Now that just what the Israelites need. - a victory. [...] They just come out of slavery where they've been stomped down and trampled on. So we got to fight them Amalekites, and Joshua, we got to win. If we don't these people will go to pieces and all our hard work will be undone. (MMM, 208).

À travers ce conte, Hurstonfait de Moses un personnage créatif dans son imagination; ce qui fait qu'il gagne plus de confiance et donne à son message une grande portée.

On constate aussi que les différentes épreuves marquant la vie de Moses témoignent de la posture de conte populaire que le roman présente. Un fait fort intéressant qui sous-tend cet argument est l'influencede l'histoire de L'ancien Testament sur le récit par lequelHurston fait raconter l'histoire de Moses qui est un personnage biblique et une légende populaire. Hurston le confirme dans sa préface affirmant qu'à travers le monde «l'Afrique, l'Amérique et les îles caraïbes, Moïse est connu comme un homme de pouvoir et de gloire que tout le monde admire:»: 'So all acrossAfrica, America, the West Indies, there are tales of Moses and greatworships of him and hispowers.'[10] De nombreuses sociétés se fient à cette légende pour bâtir une vie de consécration ou de vénération. D'autres suivent les enseignements de Moïse pour se révolter contre une quelconque injustice qui surgit.

À cela s'ajoute le style littéraire sophistiqué et surtout folklorique qui embellit l'histoire proprement racontée dans le roman en termes de références et images bibliques; ce qui fait dire à Orquidea Ribeiro que le roman se définit comme un récit biblique (biblical narrative). L'une des références les plus mirifiques du récit se trouve dans le chapitre quinze du roman où l'auteur elle-même confirme ce qu'elle a affirmé dans la préface du roman concernant la popularité de la légende de Moïse comme un conte universel. Cettemarque stylistique témoigne de l'esthétique à laquelle Ribeiro (2011) fait particulièrement allusion:

The years went by with a loping gait and left tacks all over the place. A profound calm took up in the face of Moses. It grew rugged like the mountain but held its power inside. [...] He loved the secrets of plants and animals, and the living and the giving earth .long years had passed since he embraced the religion of Jethro. He had learned to build the altars of uncut stone on earth and make the offerings, and the tribesmen had come to accept him, both as a chief second only to Jethro and as a priest. [...]

Time left its footprints all over Jethro, too. He had shrunk up in his skin considerably, so that it no longer fitted his frame. But a hopeful light had come in his eyes. He was making of Moses what he himself wanted to be - a great priest. Moses had the genius of leadership which he lacked (p.07). 
Pour Ribeiro, la référence à LaBible est significative dans la littérature africaine-américaine. Elle est source d'inspiration et se fonde sur une réalité socio-culturelle de la communauté noire américaine et sur d'autres faits historiques qui sous-tendent l'histoire racontée dans le roman. Ceci est pour Hurston un art et un moyen, en tant que porte-parole de son peuple et témoin des faits, de les restituer de façon imaginaire en combinant histoire et fiction pour représenter des faits socio-culturels d'une communauté tant malmenée et humiliée à l'instar du peuple hébreu dirigé par Moïse la fameuse figure de L'AncienTestament.

Tout compte fait, l'auteur ne rate pas sa vocation d'anthropologue et de «griotte littéraire » au point de réinventer les faits et de leur donner une version littéraire. C'est la raison pour laquelle, en faisant allusion à l'AncienTestament, Ribeiro parle d'un style moins habituel mais impressionnant:

In Moses, Man of the Mountain, Zora Neale Hurston combines fiction, folklore, religion and comedy in an unusual and even provocative manner. She employs the familiar folk preaching technique of equating Southern black history with the Biblical story of the Hebrew exodus from slavery, and obliquely introduces commentaries on the problem of racial leadership, of father-son relations and of the people's connection to God.(pp 1-2)

Il ressort de l'analyse de Ribeiro que LaBible joue un rôle fondamental dans la littérature africaineaméricaine d'émancipation. Car pour lui, la culture populaire a toujours tenté d'imiter le réel en

Une autre évidence est qu'il est facile d'interpréter Moses, Man of the Mountaincomme une légende ou un conte populaire et universel. En lisantle roman, l'on saura que diverses sociétés ont appris cette histoire, selon leur croyance, soit de l'Ancien Testament, du Coran soit de la Thora. Elles y trouvent la célèbre légende fondée sur le personnage de Moïse que Hurston a repris pour des besoins esthétiques et artistiques tout en revalorisant la légende populaire avec d'autres perspectives: littéraire, culturelle et politique.

\section{De LA SYMBoliQue du PERSONNAGE DE MOSES ET DE L'ALlegorie DU ROMAN}

Avant d'aborder l'allégorie du roman, nous allons faire une analyse onomastique du personnage de Moses pour étayer davantage sa symbolique. Moses a un nom imagé et symbolique de par son étymologie et de par son contexte. D'abord, rappelons la source! Hurston s'inspire de la légende populaire de Moïse dans L'Ancien Testament. Quoique différent dans ses origines, le personnage de Moses est créé à partir de celui de L'Ancien Testament. Seulement, pour des besoins esthétiques, Hurston a modifié l'histoire. Dans L'Ancien Testament, Moïse est de la famille des Lévis et du peuple hébreu, alors que dansleroman, Moses est Egyptien; donc il est africain. Ces versets de L'Ancien Testament le rappellent :

Un homme de la famille Lévi s'en alla prendre une fille de la famille de Lévi. La femme conçut, enfanta un fils, vit qu'il était beau et le cadra et le cacha pendant trois mois. Ne pouvant le recacher plus longtemps, elle lui trouva une caisse en papyrus, l'enduisit de bitume et de poix, y mit l'enfant et la déposa dans les joncs sur le bord du Fleuve. La sœur de l'enfant se posta à distance pour savoir ce qui lui adviendrait. Or, la fille de Pharaon descendait se laver au Fleuve, tandis que ses suivantes marchaient le long du Fleuve. Elle vit la caisse parmi les joncs et envoya sa servante la prendre. Elle ouvrit et regarda l'enfant : c'était un garçon qui pleurait. Elle eut pitié de lui : «c'est un enfant des hébreux. » dit -elle. Sa sœur dit à la fille de Pharaon « Veux-tu que j'aille appeler une nourrice chez les femmes des Hébreux ? Elle pourrait allaiter l'enfant pour toi ; » «va », lui dit la fille de Pharaon. Et la jeune fille appela la mère de l'enfant. Emmène cet enfant et allaite-le moi, lui dit la fille de Pharaon, et c'est moi qui donnerai un salaire. » La femme prit l'enfant et l'allaita. L'enfant grandit, elle l'emmena à la fille de Pharaon. Il devint pour elle un fils et elle lui donna le nom de « Moïse »; car, dit-elle, « je l'ai tiré des eaux.»(Exode, 2.1-10). [11]

Dansle roman, Hurston donne une autre version. Moses n'est pas Hébreu, mais Egyptien. En utilisant la légende de Moïse comme parabole, Hurston récrée l'histoire de L'Ancien Testament pour transcender beaucoup de problèmes socio-économiques à travers le monde. Ribeiro le precise: "In the novel, Moses is Egyptian and therefore African, rather than Hebrew, a man with conjuring and magical powers, a practitioner of hoodoo, «the fountain of mystic powers and a hope-bringer, his oppressed Hebrew followers become African-Americans (pp.34-35).

Ribeiro abien raison de clarifier que dans le roman, Moses est Egyptien et non Hébreu. C'est une autre version que Hurston a donnée à sa généalogie. D'abord, le personnage éponyme est un fils d'Amram et Jochebed, petit-fils de Mariam et d'Aaron. Il est nédans des conditions très difficiles. Sa 
mère a beaucoup souffert en le mettantau monde et lui sauver la vie. Ses parents sont des esclaves sous le joug du roi Pharaoh.

Le roi Pharoahcraint sa chute avec la multiplication du peuple hébreu caractérisé par un taux de natalité très élevé, surtout pour les bébés de sexe masculin. Par conséquent, il instaure une nouvelle loi avec intransigeance. Pour lui, tout bébé hébreu de sexe masculin doit être tué, et ceux qui défient cette loi verront leurs enfants jetés dans le Fleuve Nil. Le passage suivantrappelle à l'ordre:

The Hebrews had already been driven out of their well-built homes and shoved further back in Goshen. Then came more decrees:

Israel, you are slaves from now on. Pharaoh assumes no responsibility for the fact that some of you got old before he came to power. Old as well as young must work in his brickyards and road camps.

a- No sleeping after dawn. Fifty lashes for being late to work

b- Fifty lashes for working low

c- One hundred lashes for being absent.

d- One hundred lashes for sassing the bossman

e- Death for hitting a foreman

f- Babies take notice: Positively more boy babies allowed among Hebrews. Infants defying this law shall be drowned in the Nile. $(M M M, 2)$.

Les lois citées ci-dessus tombent et la dernière est celle qui paraît la plus ignoble aux parents de Moses qui viennent de voir leur fils naître. D'autres cas sont déjà répertoriés. La femme de Jacob a eu un enfant de sexe masculin et l'armée de Pharaoh l'a tué de même que Jacob et la mère de l'enfant. Ainsi, Moses vient de naître dans ces conditions difficiles. Ses parents ne veulent pas le voir écrasé par les lois absurdes de Pharaoh. Dès lors, ils créent des conditions de survie pour l'enfant qui sera la future légende et le seul enfant hébreu à survivre durant le règne de Pharaoh auquel il mettra fin quand il grandira.

C'est ainsi qu'une sage-femme déclare à Amram qu'il a eu un enfant et il faut lui chercher les voies et moyens de survie: «Amramyourwife has bornyou a son.» $(M M M, 13)$. Le père décide ainsi de creuser un trou sous le mur de l'intérieur de sa maison pour y garder lenouveau-né. Amramdit "Well, if we must fool the crocodiles, let us begin and do it right. Aaron, go and watch up and down the road while I dig out a cave under the inside wall of the house. It must be large enough to hold the child" $(M M M, 15)$. Ceci n'est pas une solution durable, car Pharaoh a eu écho des Hébreux qui continuent à avoir des garçons qu'ils cachent dans des roches ou dans les bois :

I see that I got you by the short hait when I told you I know what is going on about those boy babies. [....] My police have captured several of those midwives who havebeen waiting on your women folks in secret. /.../

So, now I know all about those births behind rocks and in cases and such as that. And I know all about those babies hidden out in the woods and in holes dug under house walls. My soldiers will be around to call on you. (MMM, 21-22) .

Instantanément, Amram se sent tourmenté et change d'option. Il cherche un panier où mettre le bébé pour le laisser dans le Nil : 'I got to makea good basket /.../ $(M M M, 23)$. Il ne trouve pas de solution meilleure que d'aller déposer le panier qui contient le bébé au Fleuve Nil. De temps en temps, Mariam surveille le fleuve et par hasard elle croise une délégation de la Princesse de Pharaoh venant du fleuve. Ils ont récupéré le panier, puis l'ont amené au palais du roi où Moses grandira sous la protection de celui qui opprime ses parents. C'est à partir de là que les parents de Moses se sont rassurés que leur fils deviendra une légende, car il est le seul fils d'esclave à vivre au palais du roi. Le narrateur le souligne:

Still and all, Goshen never gave up their belief in the Hebrew in the palace. It was something for men to dream about. Jochebed became a figure of importance - the mother of our Prince in the palace. Miriam told her story again and again to more believing ears. It grew with being handled until it was a history of the Hebrew in the palace, no less. Men claim to have the signs at the birth of the child, and Miriam came to believe every detail of it as she added them and retold them time and time again. Others conceived and added details at their pleasure and the legends grew like grass. (MMM, $35)$. 
C'est dans ces circonstances que Moses est entré dans l'histoire des Egyptiens. Il n'est plus considéré comme Hébreu ou esclave. Etant né en terre égyptienne et adopté par la Princesse, ce descendant d'esclave jouit d'un jus soli et d'un faux jus sanguinisqui lui ont valu une place dans la lignée des héritiers du roi Pharaoh. La rumeur court partout. Ce passagedécritl'événement: 'Inside the Palace walls was Moses, son of the Princess and second in the line for the throne of Egypt. To his mother, he was the most beautiful child in all Egypt. He wasconsidered a handsomechild by all'. (MMM, 37).

De ce fait, Moses ne peut pas être considéré comme Hébreu; il est plutôt Egyptien et africain de facto. Il est le seul Hébreu né en terre égyptienne et qui a survécu aux dures lois de Pharaoh. Il a grandi au Palais du roi et il est reconnu comme membre de la famille royale. Même si, de par les liens de sang, aucune généalogie n'aurait validé son appartenance à cette famille, de par son jus soli, il y appartient. Pourtant l'ironie derrière cette généalogie est connue. Ses parents Hébreux, Miriam, Aaron,Jochebed et Amram savent que justice sera faite un jour quand leur fils grandira.

Moses est considéré alors comme un fruit du hasard chez les Egyptiens comme chez les Hébreux; et il reste une légende populaire. Son nom est un dérivé hébraïque de «Moseh »qui signifie «retirer des eaux». Moses est tiré des eaux du Nil et il grandira comme le plus célèbre de son peuple et même de la famille qui l'a adopté. Il grandira et se battra contre le roi, son grand père adoptif, en faveur du peuple hébreu et de ses propres parents.

Pour ce qui est de l'allégorie du roman, il est possible de renvoyer l'histoire à plusieurs faits historiques qui ont marqué la communauté noire américaine. Mosesen tant queLeader et combattant fait l'objet de plusieurs analogies; c'est-à-dire que dans son incarnation, l'on voitde nombreuses allusions à des faits historiques.Son opposition au régime de Pharaohen vue de mettre fin à la servitude est une représentation idéologique du système esclavagiste et capitaliste américain des dixhuitième et dix-neuvième siècles. Les références bibliques aux lois dures de Pharaoh sont assimilables aux lois absurdes de Jim Crow Law des USA. Cet argument est partagé par P. Suresh, D. Angeline Jeba (2018) :
In Moses, Man of the Mountain, Hurston retells TheOld Testament story of Moses, chronicling his quest to lead the Israelites out of slavery under the Egyptians and to freedom. The Israelites' struggle out of slavery is used to parallel and analogise the same struggle faced by black slaves in the United States. Hurston traces Moses's life from the day he is launched into the Nile River in a reed basket, to his development as a great magician, to his transformation into the heroic rebel leader, the Great Emancipator. From his dramatic confrontations with Pharaoh to his fragile negotiations with the wary Hebrews, this very human story is told with great humour, passion and psychological insight-the hallmarks of Hurston as a writer and champion of black culture. (p.119)

Toujours par analogie, l'on peut voir dans le soulèvement que Moses a mené contre Pharaoh des souvenirs de la Guerre civile américaine dont l'une des causes principales fut l'esclavage. Mais,au delà de tout cela, LaBible était aussi pour les esclaves d'origine africaine une source de motivation à apprendre à lire pour survivre et supporter la vie difficile qu'ils menaient avant d'arriver, eux aussi,à la Terre promise dont ils rêvaient. Ils devaient lire La Bible pour comprendre beaucoup de choses selon Ribeiro (2011):

TheBible has an important role in the African American literary tradition. One of the strongest motivations for slaves to learn to read so that they might study the Bible themselves for messages of hope, looking for passages that said something besides "obey your masters" (pp.1-2).

Cette allusion biblique se lit dans Moses, Man of the Mountainà travers le personnage de Moses. Ce dernier se révolte contre son faux grand-père, sauve son peuple et l'amène à la Terre promise. Ainsi, pour montrer la popularité de la légende de Moses chez les Africains-Américains, certains leaders étaient surnommés «Moses». En guise d'exemple, Martin Luther KING Jr., un dirigeant influent du Civil RightsMovement, s'appelait «Modern Moses» en son temps. Lui aussi a porté le flambeau de la liberté et a donné sa vie pour la cause des Africains-Américains à l'image de Moses le personnage biblique. Et même dans le roman de Hurston, l'on voit des faits qui auraient inspiré les dirigeants de mouvements dans les années 1960. Le début du chapitre 27 du roman rappelle les grands événements du mouvement des droits civiques des noirs américains. Le narrateurdécrit : 
The people cried when Moses told them. He had expected wild clamor; the sound of cymbals and exultant singing and dancing. But, the people wept out of their eyes. Goshen was very still. [...]"Free at last! Free at last! Thanks God Almighty I'm free at last." (MMM, 180).

Dans ce passage, Moses devient plus qu'un messie et un redresseur de tort. Il est le tambour major de justice qui aurait inspiré Dr. Martin Luther KING Jr. On voit dans Moses, Man of the Mountainune représentation paradigmatique de la légende populaire qui aurait inspiré l'un des plus célèbres leaders africains-américains, en l'occurrence Dr. Martin Luther KING Jr., qui dans son discours «I Have a Dream» du 28 août 1963 à Washington D.C, avait terminé ses propos avec les mêmes mots que Moses a adressés à son peuple. Bien que Hurston ne donne pas à ses personnages une appartenance à la communauté africaine-américaine, des études ont été menées sur cette allégorie biblique de Moses et l'histoire réelle des Noirs américains dont le sort fut l'une des préoccupations majeures de Hurston. Selon P. Suresh et D. Angeline Jebab (2018),cela paraît très évident et le roman se définit comme un récit biblique: 'Thenovelisthus a commentary on the nature of oppression and the struggle for freedom and equality. Whereas in her other novels Hurston employs ample use of biblical allusion to enrich her narratives, Moses, Man of the Mountain is primarily a Bible narrative that is retold from a modern perspective' (119)

D'autres interprétations de l'histoire sont possibles par rapport à l'allégorie du roman $M M M$, mais celle à laquelle elle est plus proche est l'histoire des Noirs américains.L'analyse de Deborah E. McDowell [12] est l'un des commentaires les plus convaincants sur l'étude de l'œuvre de Hurston.

Moses, c'est le fameux personnage de L'Ancien Testament (Moïse) qui est à la fois un prophète, une incarnation de Dieu, une puissance, bref une figure qui dénonce l'injustice. Il est cette parole de Dieu, «je suis ce que je suis». C'est une rétrospection de l'histoire de Moïse qui était mis dans un panier et jeté dans le fleuve Nil qui est revenu accomplir une mission divine. Cette légende a une influence sur le génie imaginaire de Hurston. Cette création romanesque du personnage nous rappelle le personnage type que Raimond (2000) explique dans cette citation :

Il est frappant de constater, quand on étudie la genèse de beaucoup de romans, l'importance d'une sorte de décision initiale du romancier, d'acte créateur qui pose en quelques mots le sujet qu'il a l'intention de traiter, l'esprit dans lequel il entend le faire, la signification profonde de l'histoire qu'il se propose de raconter (p.56). [13]

Dans Moses, Man of the Mountain, la symbolique est ancrée dans cette philosophie de liberté engagée dans un combat permanent contre l'oppression et l'injustice en général. On y voit clairement une dialectique entre le maître et l'esclave qui se traduit par l'exploitation et la domination du peuple hébreu par les Egyptiens sous l'égide de Pharaoh. Ainsi, le héros Moses, dans sa quête d'identité et sa soif pour la liberté voit son séjour à la montagne comme un tournant décisif dans son combat contre l'injustice.

L'image de la montagneest très symbolique dans le récit de Hurston. Elle est d'abord pour Moses un lieu de découverte de soi et aussi celle de Dieu par une révélation. C'est sur la montagne que Moses a reçu la mission et l'ordre de Dieu d'aller libérer son peuple en lui dotant d'un pouvoir magique. Le narrateur raconte son séjour sur la montagne et la révélation de Dieu :

Moses sat up on the mountain passing nations through his mind. Way late in the day he climbed up to a place where he had been resting every afternoon for a long time. Ha was watching the development of a family of reptiles under a rock beneath a bushy growth. So he went - up putting words into the mouth of the various little creatures that he saw on the way. What these creatures had to say about people had plenty of seasoning. /.../

"Moses, "spoke a great voice which Moses did not know, 'take off your shoes."

"How come , lord? I know no voice like that can't be like mine."

"this ground you are walking on is holy ground.

Take off those shoes."

"yes, sir, Lord." Moses loosened his shoes and took the off without once talking his eyes off of the beaming bush that did not wither. Mosesstoodbare-footed and trembledwithawe (MMM, 125-126).

L'arrivée de Moses à la montagne est une étape déterminante de sa longue marche vers la Terre promise qui est un rêve majeur et un vif souhait de libérer ses frères de sang. Dieu lui fait savoir qu'il 
lui donnera le pouvoir pour assurer comme mission la libération de son peuple qui vit sous l'esclavage. La montagne est alors un lieu de révélation et par anticipation une annonce de l'accès à la Terre promise. Car il est garanti par Dieu qui lui procure d'un pouvoir magique et surhumain qui fera tomber le roi Pharaoh. La révélation continue et se lit dans ces lignes :

\footnotetext{
Moses gathered his strength and stopped. He seized the snake by the tail expecting to be bitten immediately. But except for a curious tremor of life that somehow communicated itself to the hand of Moses and from his hand to his arm throughout his body, might have been the wooden image of a snake. It was heavy for its length in wood, it was stiff and motionless like stone. Moses was amazed by the writhing serpent on the ground could have become so quickly the lifeless thing in his hands. It was a walking stick carved in imitation of a snake.

"Moses, put it down." Moses dropped the rod and it became a living snake again. /.../

"Moses , I wan you to go down Egypt ."

"Into Egypt? How come , Lord? Egypt is no place for me to go."

"I said Egypt, Moses. I heard my people, the Hebrews when they cried, when they kept on groaning to me for help. I wan you to go down and tell that Pharaoh. I say to let my people go. "The won't pay me no attention, lord. I know he won't."

"Go ahead, like I told you, Moses, I am tired of hearing the groaning in my ear. I mean to overcome Pharaohthis time; /.../

"You go on; I'll go with you. Open your mouth and I 'll speak for you.

"Well, Lord, if I go, tell me what to say; they won't believe in me." Moses said with hopeless resignation. "I don't even know your name. Who must I tell them sent me? "Tell them, I AM WHAT I AM"

"Yes, sir, I'll so tell them , but I know it won't do any good." (MMM, 126-127).
}

À ce niveau, l'histoire devient de plus en plus captivante en termes d'images et de symbolique. La montagne elle-même est un lieu saint comme Dieu l'a dit à Moses en lui demandant d'enlever ses chaussures. Moses prenait la montagne comme un lieu ordinaire, un simple refuge mais ce lieu devient sacré pour lui et il y découvre les miracles de Dieu. Moses a vu Dieu et devient un homme de la montagne en sus de sa légende comme un homme des eaux. Là, apparaît la métaphore biblique du titre qui a une portée philosophique et métaphysique.

Le titre du roman vient donc de cette double métaphore biblique dont la symbolique se traduit par une synthèse des miracles de Moses qui a été l'homme des eaux et maintenant devenu l'homme de la montagne. C'est ainsi que Dieu lui confie la mission divine de libérer le peuple hébreu.L'arrivée du peuple de Moses à la Terre promise est imminenteet certaine. Car il sait certes que le peuple qu'on lui a assigné de libérer est sous la domination d'un redoutable roi oppresseur mais, lui aussi, est garanti dans sa mission par un pouvoir non seulement magique mais suprême. Il est doté de pouvoir magique par le créateur de l'univers. Force est de croire que Moses vaincra Pharaoh. Son peuple triomphera et arrivera à la Terre promise.

\section{CONClusion}

L'intertextualité et les allusions bibliques dansMoses, Man of the Mountainreposent fortement sur la mythologie judéo-chrétienne que Hurstona matérialisée dans son texte à travers une stratégie narrative particulière et des figures de styles renvoyant tantôt à des images, tantôt à des animaux, et à des objets de la nature. Ce sont,littéralement,des emblèmes du cosmos en miniature.Cette technique narrative dite cosmogonique revêt d'une esthétiquequi abonde l'œuvredesymboles et d'allégories.En d'autres termes,Hurston utilise en abondance des images bibliques pour mettre à nue l'injustice à laquelle elle fait allusion. Les nombreuses et absurdes lois de Pharaohsont, par analogie, celles du Jim Crow Law des USA après la Guerre civile siècles qui houspillaientles Noirs et les privaient de leurs droits civiques et moraux. C'est pour cette raison queVincent Cucarella-Ramon (2016)soutientcespropos : 'Hurston's Moses, Man of the Mountain can also be read as an exercise that foregrounds the status and future direction of African American liberation discourses, in which black women priestesses play a central role' (p.79).[14]

Au terme de cette analyse, l'on s'aperçoit qu'une lecture du roman historique de Hurston offre plusieurs perspectives de développement liées à son caractère spécifique de roman politique par essence. Mais, cela ne réduit en aucun cas sa dimension littéraire au sein de la littérature américaine à laquelle il appartient et dans laquelle il s'affirme, pour l'auteur, comme moyen de dénonciation de la pire pratique du système esclavagiste. 
Quoique fictif, Moses, Man of the Mountainoffre une relecture détaillée intéressante de deux faitssocio-culturels et politiques. Autrement dit, le personnage symbolique de Moses influence ses lecteurs à plus d'un titre. Il est admiré en tant que Leader et libérateur du peuple d'Israël et redresseur de tort pour les victimes de quelconque injustice.

\section{AUTHORS' BIOGRAPHY}

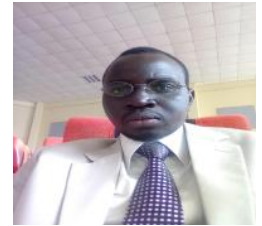

Dr. Alassane Abdoulaye DIA is a researcher and Lecturer of English at the Université Gaston Berger de Saint-Louis, Senegal (West Africa). He holds a Ph.D. in African and American literatures (Comparative Literature) and is author of two books. The Voice of the Tradition in the African Novel: Chinua Achebe's Artistic Use of Orature in Things Fall Apart and Anthills of the Savannah (2015), The Power of Peace and Love: An African Tale of Wisdom (2020), and a range or scholarly articles in both English and French.

\section{RÉFÉRENCES BIBLIOGRAPHIQUES}

[1] Dia, A. A. (2020). «Structure et architecture textuelledansTheir Eyes Were Watching God de Zora Neale Hurston » in International Journal of Humanities, Social Sciences and Education, Vol. 7, n 6, June, pp.715

[2] Suresh, P. \& D. Angeline Jeba. (2018) 'Black Leadership of Moses and Enslaved Hebrew in Zora Neale Hurston's Moses, Man of the Mountain' in Eurasian Journal of Analytical Chemistry, Vol. 13, $n^{\circ}$ 4, pp. $118-124$

[3] Etudeslittéraires. Intertextualité: accessible sur https://www.etudes-litteraires.com/figures-destyle/intertextualite.php. Date de consultation: le 29 juin, 2020.

[4] Julia Kristeva. (1969). Pour une sémiologie de programmes. Paris : Collections Points.

[5] Tine, Alioune. (1985). «Pour une théorie de la littérature africaine écrite l'oralité feinte comme code de représentation de la littérature négro-africaine.» in Présence Africaine, $\mathrm{n}^{\circ}$ 133-134.

[6] Dictionnaire des mythes littéraire.ed. Jean-Paul Bertrand. Paris: Editions du

[7] Ibid.

[8] Gates Jr., H. L. (1991) Postface.Moses, Man of the Mountain.Zora Neale Hurston. New York :HaperPerennial Books.

[9] Ribeiro, O. (2001). 'Biblical Narratives and Popular Culture': Zora Neale Hurston's Moses, Man of the Mountain.Conference paper at theIV CONGRESSO INTERNACIONAL DA ASSOCIAÇÃO PORTUGUESA DE LITERATURA COMPARADA (version électronique

[10] Hurston, Z. N.(1939). Preface.Moses, Man of the Mountain.New York: Harperperennial Modern Classics.

[11] La Bible: Ancien Testament 1 (Traduction œcuménique de la Bible), Paris : Editions du Cerf, 1975.

[12] Deborah E. McDowell. (1991). Lines of Descent/DescentingLines.Postface. Moses, Man of the Mountain. New York: Harperperennial Modern Classics

[13] Raimond, M. (2000). Le Roman. Paris: Armand Collin.

[14]Cucarella-Ramon,Vincent. (2016). 'The Aesthetics of Healing in the Sacredness of the African American Female's Bible: Zora Neale Hurston's Moses, Man of the Mountain' in Alicante Journal of English Studies Vol. 29, pp. 69-90.

Citation:Dr. Alassane Abdoulaye DIA. "Intertextualité, allégorie et allusions bibliques dans Moses, Man of the Mountain de Zora Neale Hurston" International Journal of Humanities Social Sciences and Education (IJHSSE), vol 7, no. 7, 2020, pp. 56-66. doi: http://dx.doi.org/10.20431/2349-0381.0707006

Copyright:@ 2020 Authors. This is an open-access article distributed under the terms of the Creative Commons Attribution License, which permits unrestricted use, distribution, and reproduction in any medium, provided the original author and source are credited. 